\title{
Standing crops of planktonic ciliates and nanoplankton in oceanic waters of the western Pacific
}

\author{
Toshikazu Suzuki*, Nobuyuki Yamada**, Akira Taniguchi \\ Graduate School of Agriculture, Tohoku University, Sendai 981, Japan
}

\begin{abstract}
The vertical distribution of planktonic ciliates and nanoplankton was investigated in 3 types of oceanic waters in the western Pacific. Ranges of their standing crops, in abundance and biomass, were 50 to 2540 cells $1^{-1}$ and $4.89 \times 10^{4}$ to $6.32 \times 10^{6} \mathrm{pg} \mathrm{Cl}^{-1}$ for ciliates and $7.2 \times 10^{4}$ to $1.97 \times$ $10^{6}$ cells $\mathrm{l}^{-1}$ and $2.45 \times 10^{5}$ to $4.92 \times 10^{7} \mathrm{pg} \mathrm{C}^{-1}$ for nanoplankton in the spring subarctic water, $<1080$ cells $\mathrm{l}^{-1}$ and $<1.27 \times 10^{6} \mathrm{pg} \mathrm{C}^{-1}$ for ciliates and $7.5 \times 10^{4}$ to $2.76 \times 10^{6}$ cells $\mathrm{l}^{-1}$ and $1.01 \times 10^{5}$ to $1.03 \times 10^{7} \mathrm{pg} \mathrm{Cl}^{-1}$ for nanoplankton in the fall subarctic water, and $<570$ cells $^{-1}$ and $<1.59 \times 10^{6} \mathrm{pg} \mathrm{C}$ $\mathrm{l}^{-1}$ for ciliates and $1.45 \times 10^{5}$ to $3.18 \times 10^{6} \mathrm{cells}^{-1}$ and $3.05 \times 10^{5}$ to $2.62 \times 10^{7} \mathrm{pg} \mathrm{Cl}^{-1}$ for nanoplankton in the subtropical water. The standing crop of ciliates, as a whole, was positively correlated to that of nanoplankton especially in biomass: $B_{c}=0.211 \times B_{n}{ }^{0994}, \mathrm{r}=0.81, \mathrm{p}<0.001$, where $B_{\mathrm{c}}$ and $B_{\mathrm{n}}$ are biomass of ciliates and nanoplankton, respectively. This suggests that nanoplankton and ciliate stocks are tightly linked in oceanic waters.
\end{abstract}

KEY WORDS: Planktonic ciliates - Nanoplankton - Quantitative relationship - Oceanic waters

\section{INTRODUCTION}

Planktonic ciliates are abundant and ubiquitous in every ocean (Pierce \& Turner 1992). They are known to ingest picoplankton or bacterioplankton (Sherr \& Sherr 1987. Bernard \& Rassoulzadegan 1990) and nanoplankton (Gifford 1985, Verity 1985). Some microplankton, in a size range similar to or larger than the planktonic ciliates, can also serve as ciliate prey (Wessenberg \& Antipa 1970, Ishiyama et al 1993). Previous studies on the standing crops and feeding activities of planktonic ciliates have demonstrated that they can be the dominant heterotrophs in the microbial loops (Sorokin 1981, Porter et al. 1985). Lynn \& Montagnes (1991) compared bacterioplankton biomass with ciliate biomass reported from a variety of marine environments and found a poor correlation between the two on a logarithmic scale. On the other hand, an

Present addresses:

-Faculty of Fisheries, Nagasaki University, Nagasaki 852. Japan

- Sendai Municipal Institute of Public Health, Sendai 983. Japan analysis of biomasses of ciliates and nanoplankton in the North Atlantic Ocean revealed a significant negative correlation between autotrophic nanoplankton and ciliates but a non-significant correlation between heterotrophic nanoplankton and ciliates (Stoecker et al. 1994b). However, there are few data on nanoplankton and ciliates for the oligotrophic open ocean, where the role of microbial components may be more important. This study analyzes the relationship between both components based on the data sets obtained by consistent investigations in the western Pacific Ocean.

Planktonic ciliates, except for the autotrophic Mesodinium rubrum, are classified as heterotrophs or mixotrophs (Stoecker et al. 1989, Suzuki \& Taniguchi 1993). Although both may feed on heterotrophic nanoplankton, the latter require autotrophic nanoplankton to continuously sequester functional chloroplasts (Stoecker et al. 1988, Stoecker 1991). Therefore, we considered quantitative relationships for the following 4 pairs: between total ciliates and total nanoplankton, between heterotrophic ciliates and total nanoplankton, between mixotrophic ciliates and total nanoplankton, and between mixotrophic ciliates and autotrophic nanoplankton. 


\section{METHODS}

Water samples were collected with a CTD-Rosette Multi Sampler from 6 to 12 layers in the top 100 or $200 \mathrm{~m}$ of the water column in 3 types of oceanic waters of the western Pacific, i.e. spring subarctic (6 stations), fall subarctic ( 3 stations) and subtropical (6 stations) waters on 3 cruises of RV 'Hakuho Maru' (Fig. 1, Table 1). Vertical profiles of water temperature were recorded with the CTD. A total of 131 water samples were analyzed to determine chlorophyll a (chl a) concentration by a fluorometric method (Strickland \& Parsons 1972) and abundances and size composition of nanoplankton and ciliate communities. Plankters of 2 to $20 \mu \mathrm{m}$ in equivalent spherical diameter (ESD) were categorized as nanoplankton except ciliates less than $20 \mu \mathrm{m}$ in ESD which were counted as ciliates.

For the nanoplankton cell enumeration, 25 to $50 \mathrm{ml}$ aliquots were fixed with glutaraldehyde $10.5 \%$ final concentration) and stained with proflavine $(0.00066 \%$ final concentration) and then filtered onto a black prestained Nuclepore polycarbonate filter $(0.6 \mu \mathrm{m}$ pore size, $25 \mathrm{~mm}$ diam.) (Haas 1982). The filter was mounted on a slide and kept frozen at $-80^{\circ} \mathrm{C}$ until examination. Slides were examined with an epifluorescence microscope (Nikon Optiphoto) at $1000 \times$ with B-excitation light (line spectra of 405 and $435 \mathrm{~nm}$ and continuous spectrum around $490 \mathrm{~nm}$ ). More than 50 cells in the dozens of randomly selected microscopic fields were counted for the spring subarctic samples, and over 100 fields for fall subarctic and subtropical samples, which were equivalent in sample size to $0.03-1.6 \mathrm{ml}$ for the spring subarctic water (detection limit: 600 cells $\mathrm{l}^{-1}$ ) and to $0.12-0.48 \mathrm{ml}$ for the fall subarctic and subtropical waters (detection limit: 2000 cells $1^{-1}$ ). Cell size was measured simultaneously for individual cells. Nanoplankton cell carbon was calculated based on Strathmann's (1967) equation.

Water samples for ciliate cell counts were fixed with neutralized formaldehyde ( $2 \%$ final concentration). Counts and size measurement were done by Utermöhl method using an inverted epifluorescence microscope (Olympus IMT-2) at $200 \times$ on $100 \mathrm{ml}$ (detection limit: 10 cells $!^{-t}$ ) and cell volume was calculated individually. The cell volume was converted to carbon biomass by using the factor of $0.14 \mathrm{pg} \mathrm{C} \mathrm{mm}^{-3}$ (Putt \& Stoecker 1989). Mixotrophic ciliates were identified by possession of chlorophyll pigments with bright red fluorescence under a B-excitation, which is different from the spotted and faded red emission of the autotrophic plankton in food vacuoles of ciliates. Mesodinium rubrum, if any, were omitted because of their autotrophic mode and absence of feeding relationship with nanoplankton (Lindholm 1985).
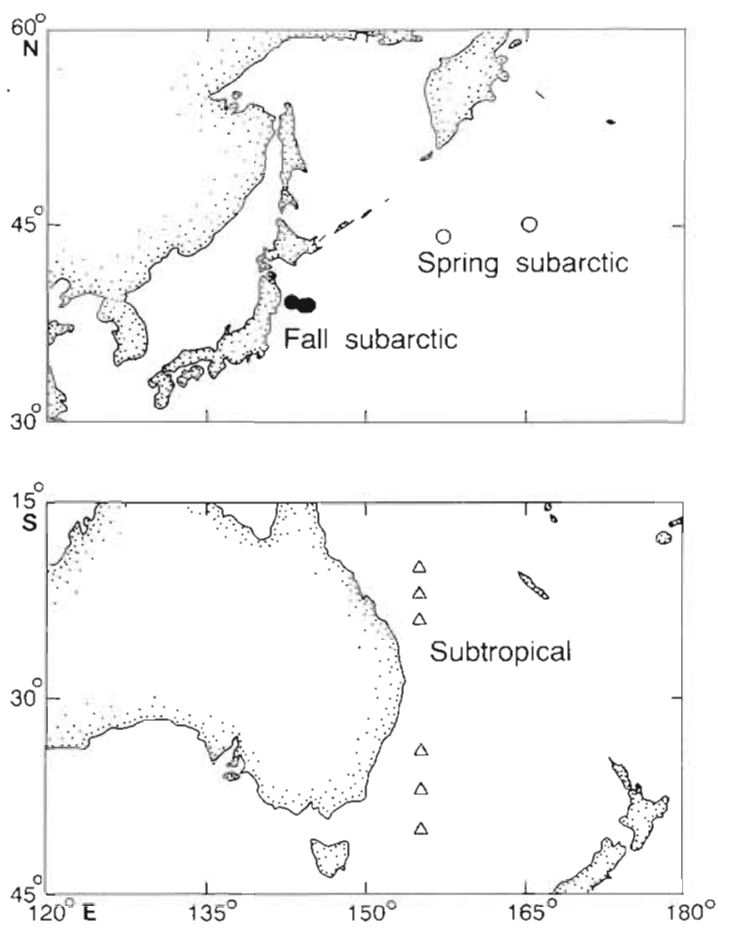

Fig. 1. Location of sampling stations. (0) Spring subarctic water (5 points are almost overlapping around $45^{\circ} \mathrm{N}, 165^{\circ} \mathrm{E}$ ); $(\bullet)$ fall subarctic water; $(\Delta)$ subtropical water

\section{RESULTS}

Autotrophic nanoplanktonic populations consisted of pigmented flagellates and diatoms. The flagellates always predominated over the diatoms in abundance and biomass. All heterotrophic nanoplankters were heterotrophic flagellates. Both auto- and heterotrophic nanoplankton were dominated by small cells, less than $4 \mu \mathrm{m}$ in ESD. The mixotrophic ciliates observed were dominated by cells of around $30 \mu \mathrm{m}$ ESD. Heterotrophic ciliates consisted of both aloricate forms and tintinnids, the aloricate forms predominated in abundance and biomass over tintinnids in most samples The dominant size of the heterotrophic ciliates was around $20 \mu \mathrm{m}$ in ESD.

Standing crops in abundance $\left(A_{c}\right)$ and biomass $\left(B_{c}\right)$ of total ciliates in spring subarctic water (50 to 2540 cells $\mathrm{I}^{-1}, 4.89 \times 10^{4}$ to $6.32 \times 10^{6} \mathrm{pg} \mathrm{C} \mathrm{I}^{-1}$ ) were larger than those in fall subarctic $\left(<1080\right.$ cells $\mathrm{l}^{-1},<1.27 \times 10^{6} \mathrm{pg} \mathrm{C}$ $\mathrm{l}^{-1}$ ) and subtropical waters ( $<570$ cells $\mathrm{l}^{-1},<1.59 \times 10^{6}$ pg $\left.\mathrm{C}^{-1}\right)$. Abundance of total nanoplankton $\left(A_{n}\right)$ showed a different trend, being higher in subtropical $\left(1.45 \times 10^{5}\right.$ to $3.18 \times 10^{6}$ cells $\left.1^{-1}\right)$ than in fall subarctic $\left(7.5 \times 10^{4}\right.$ to $2.76 \times 10^{6}$ cells $\left.^{-1}\right)$ and spring subarctic waters $\left(7.2 \times 10^{4}\right.$ to $1.97 \times 10^{6}$ cells $\left.1^{-1}\right)$ (Table 1$)$. How ever, in terms of biomass, nanoplankton $\left(B_{\mathrm{n}}\right)$ in spring subarctic $\left(2.45 \times 10^{5}\right.$ to $\left.4.92 \times 10^{7} \mathrm{pg} \mathrm{C}^{-1}\right)$ was higher 


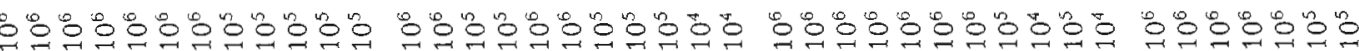
$\times \times \times \times \times \times \times \times \times \times \times \times \times \times \times \times \times \times \times \times \times \times \times \times \times \times \times \times \times \times \times \times \times \times \times \times \times \times \times \times \times$

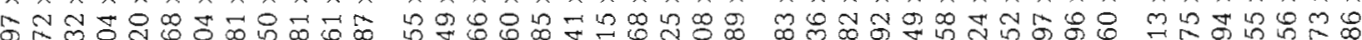

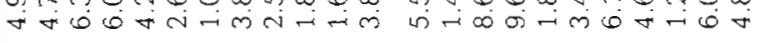

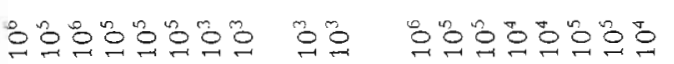
$\times \times \times \times \times \times \times \times \bar{x} \times \bar{x} \times \times \times \times \times \times \times \times \bar{\square} \times$

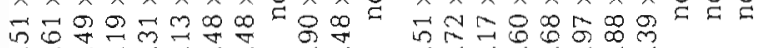

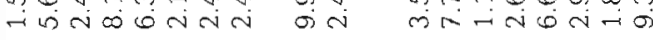
m-intiritimin is

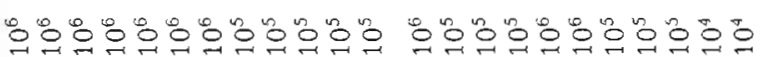

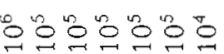

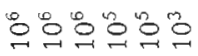

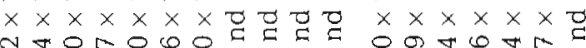

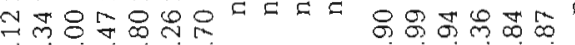

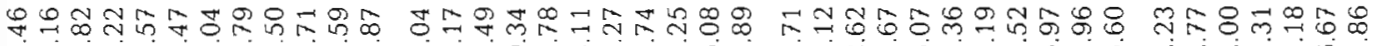

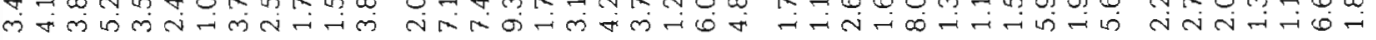

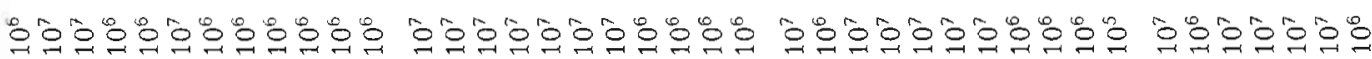

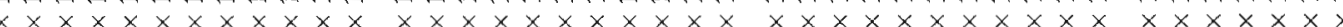

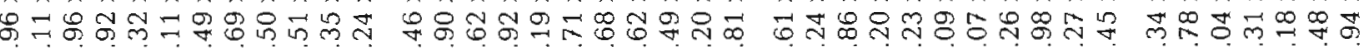

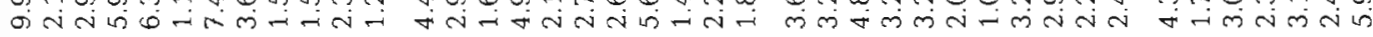

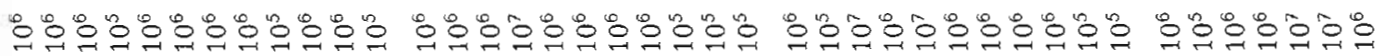

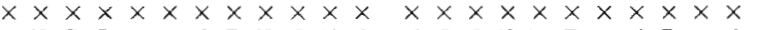

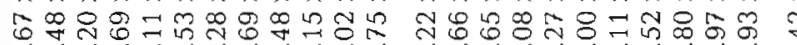

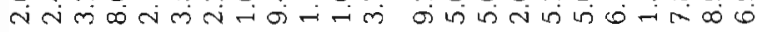
$\times \times \times \times \times \times \times \times \times \times \times \times \times \times \times \times \times 10$

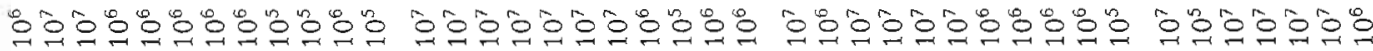

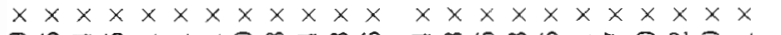

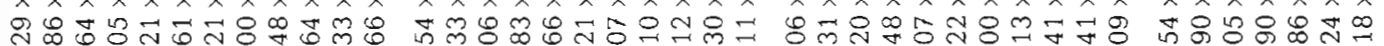

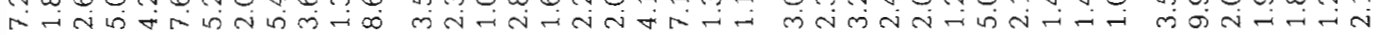

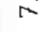

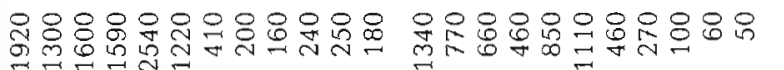

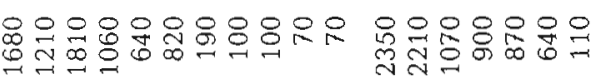

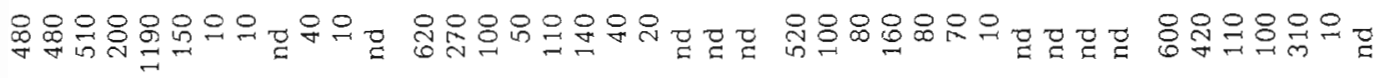

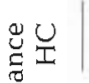

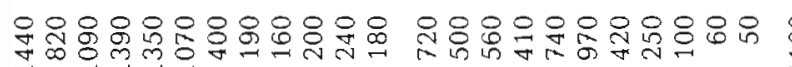

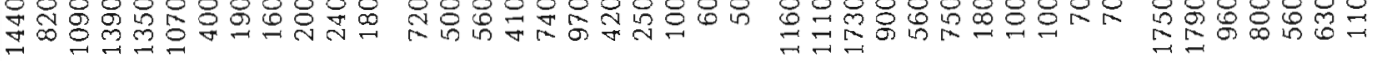

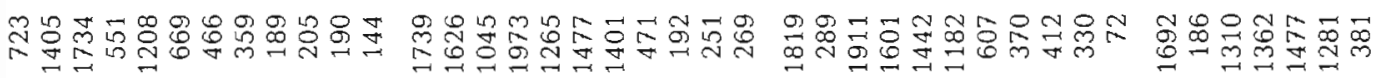

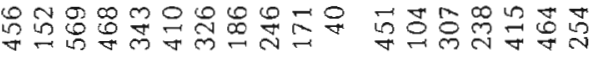

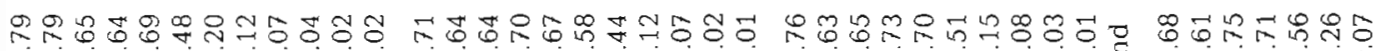
$000000000000000000000000000000000=0000000$

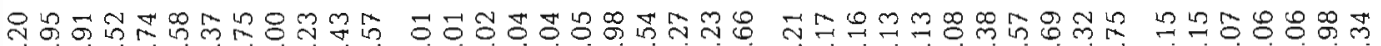

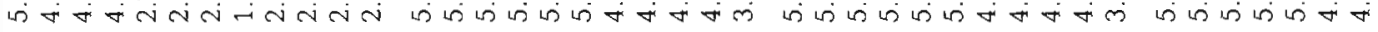




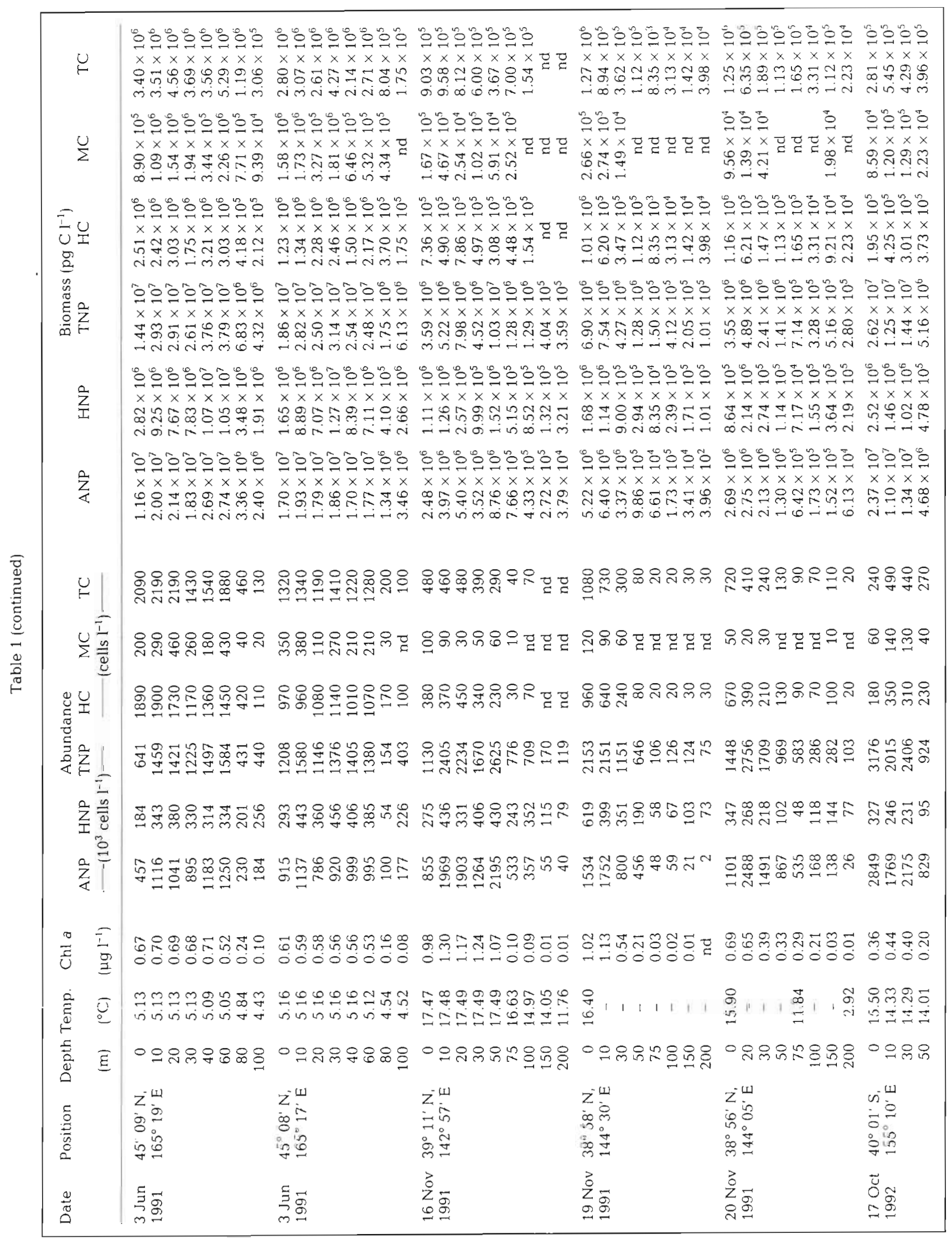




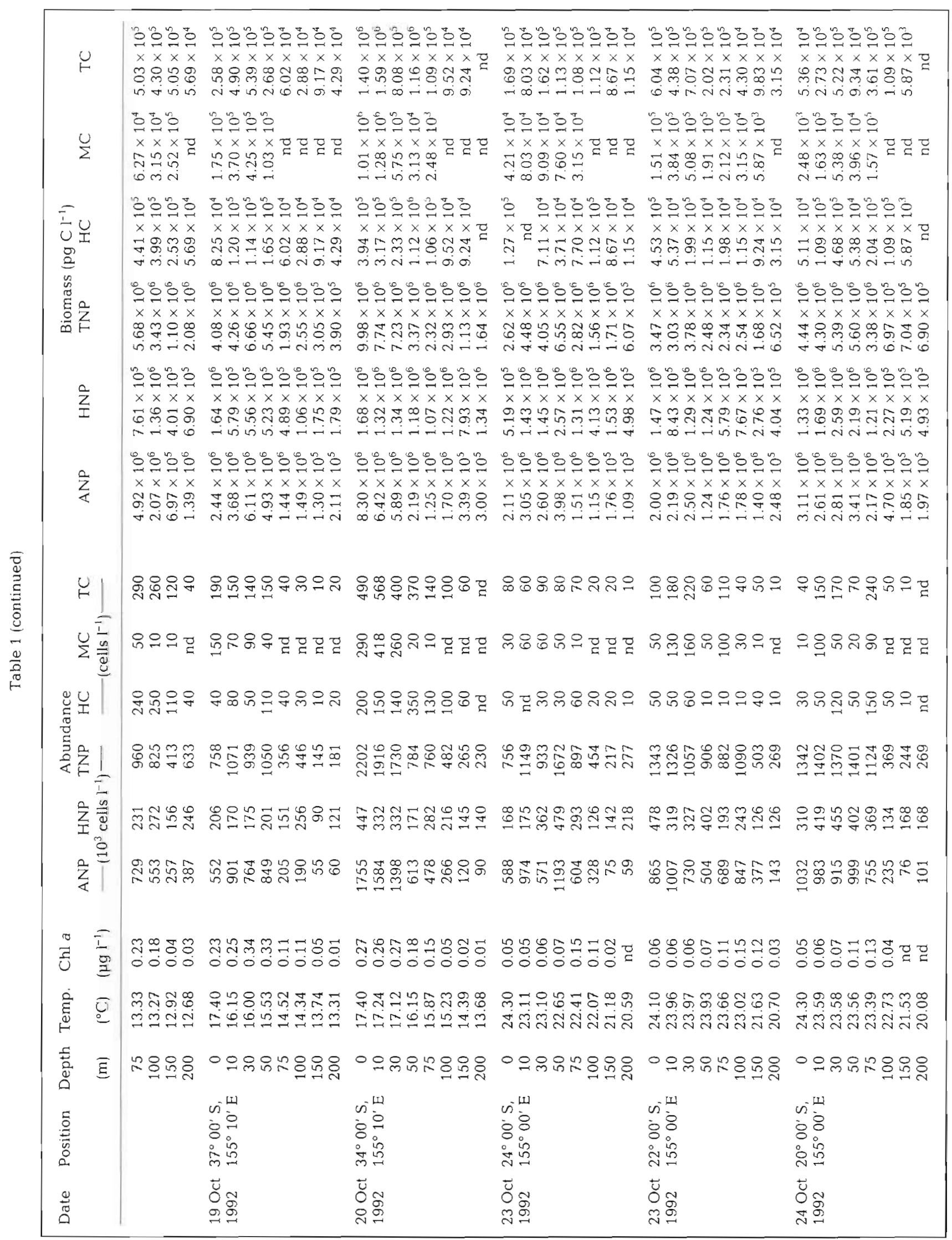



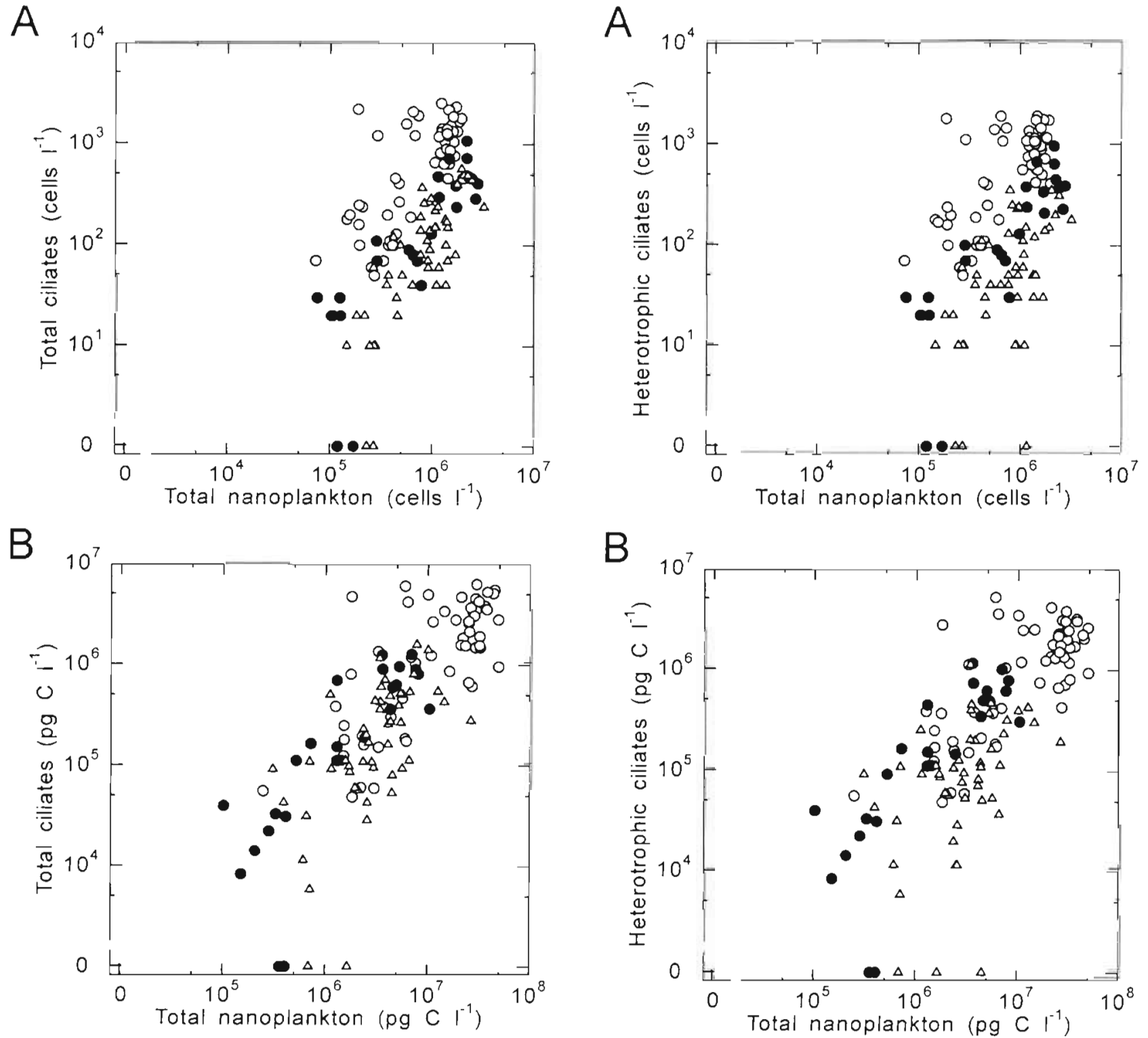

Fig. 2. Relationship in (A) abundance and (B) biomass between total nanoplankton and total planktonic ciliates. (O) Spring subarctic wateri $(\bullet)$ fall subarctic water $(\Delta)$ subtropical water

than in fall subarctic $\left(1.01 \times 10^{5}\right.$ to $\left.1.03 \times 10^{7} \mathrm{pg} \mathrm{C}^{-1}\right)$ and subtropical waters $\left(3.05 \times 10^{5}\right.$ to $\left.2.62 \times 10^{7} \mathrm{pg} \mathrm{Cl}^{-1}\right)$ (Table 1). Positive correlations were observed both between $A_{\mathrm{c}}$ and $A_{\mathrm{n}}$ and between $B_{\mathrm{c}}$ and $B_{\mathrm{n}}$ (Fig. 2) on logarithmic scales. When 4 samples with zero $A_{c}$ were excluded, the regression equation in abundance over 3 oceanographic regimes was: $A_{c}=3.24 \times 10^{-4} \times A_{n}{ }^{0996}$ $(\mathrm{r}=0.61, \mathrm{p}<0.001, \mathrm{n}=126)$. On the other hand, the regression equation in biomass was: $B_{\mathrm{c}}=0.211 \times B_{\mathrm{n}}{ }^{0.944}$ $(r=0.81, p<0.001, n=126)$. The correlation coefficient observed in biomass $(\mathrm{r}=0.81)$ was significantly larger $(\mathrm{p}<0.01)$ than that in abundance $(\mathrm{r}=0.61)$.

Fig. 3. Relationship in (A) abundance and (B) biomass between total nanoplankton and heterotrophic planktonic ciliates. (O) Spring subarctic water; $(\bullet)$ fall subarctic water $(\Delta)$ subtropical water

The relationship between heterotrophic ciliates and total nanoplankton (Fig. 3) was almost the same as that between total ciliates and total nanoplankton, since abundance $\left(A_{\mathrm{hc}}\right)$ and biomass $\left(B_{\mathrm{hc}}\right)$ of heterotrophic ciliates were generally higher in spring subarctic $(50$ to 1900 cells l$^{-1}, 4.89 \times 10^{4}$ to $5.22 \times 10^{6} \mathrm{pg} \mathrm{Cl}^{-1}$ ) than in fall subarctic $\left(<960\right.$ cells $\left.\mathrm{I}^{-1},<1.16 \times 10^{6} \mathrm{pg} \mathrm{Cl}^{-1}\right)$ and sub-

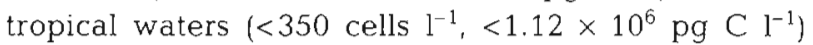
(Table 1). The overall regression equation in abundance excluding 5 exceptional samples with zero $A_{\text {hc }}$ was: $A_{\mathrm{hc}}=2.00 \times 10^{-3} \times A_{\mathrm{n}}{ }^{0842}(\mathrm{r}=0.50, \mathrm{p}<0.001, \mathrm{n}=$ 125). The regression equation in biomass was: $B_{\mathrm{hc}}=$ 

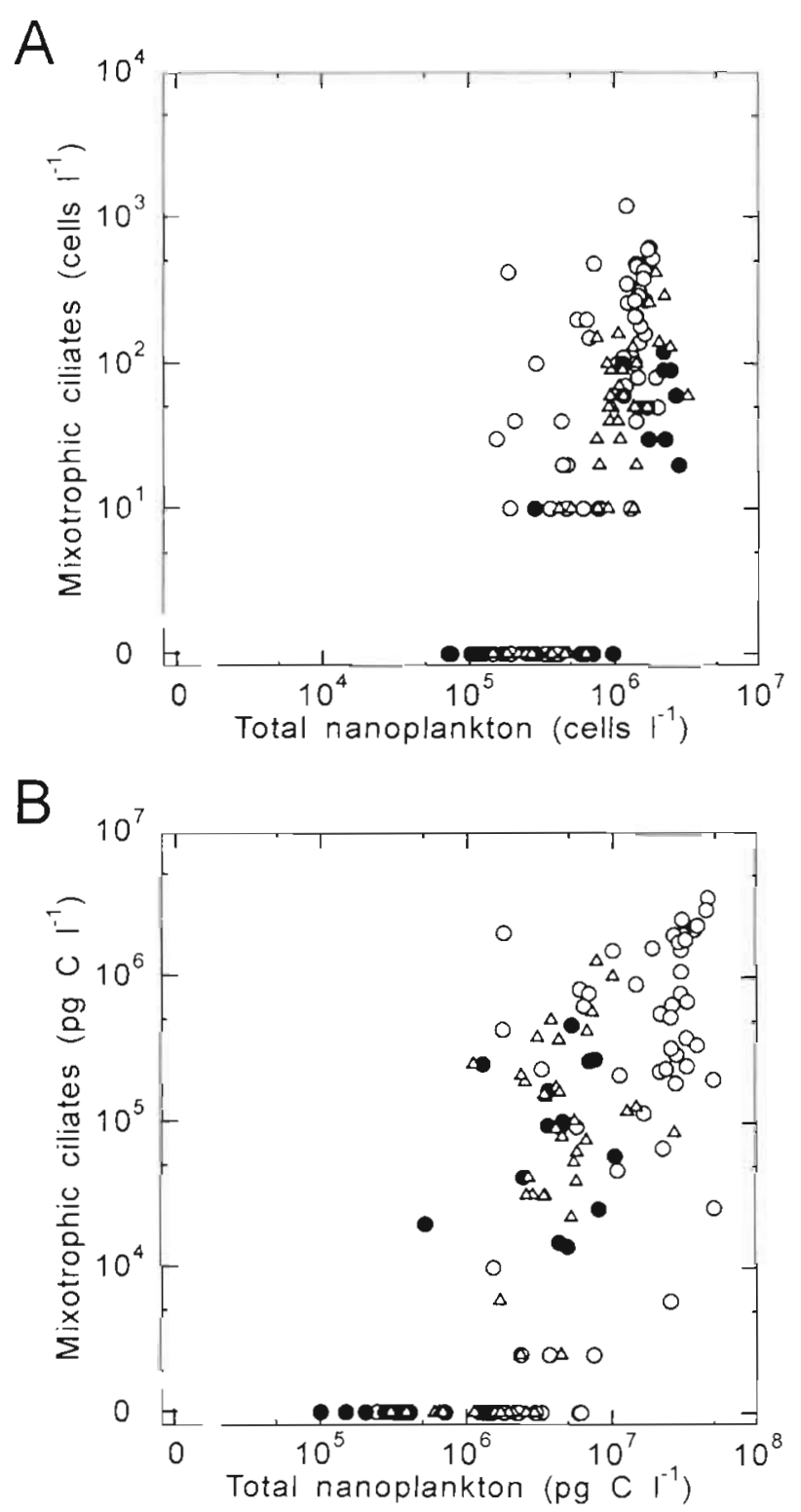

Fig. 4. Relationship in (A) abundance and (B) biomass between total nanoplankton and mixotrophic planktonic ciliates. (O) Spring subarctic water; ( fall subarctic water; ( $\Delta$ ) subtropical water

$0.478 \times B_{\mathrm{n}}{ }^{0.868}(\mathrm{r}=0.77, \mathrm{p}<0.001, \mathrm{n}=125)$. The correlation coefficient in biomass $(\mathrm{r}=0.77)$ was significantly higher $(p<0.001)$ than in abundance $(r=0.50)$.

Slight differences were observed in standing crop of mixotrophic ciliates over 3 oceanographic regimes, i.e the highest values of mixotrophic ciliate abundance $\left(A_{\mathrm{mc}}\right)$ were 1190,120 and 420 cells $1^{-1}$ and those of biomass $\left(B_{\mathrm{mc}}\right)$ were $3.51 \times 10^{6}, 4.67 \times 10^{5}$ and $1.28 \times 10^{6} \mathrm{pg} \mathrm{Cl}^{-1}$ in spring subarctic, fall subarctic and subtropical waters, respectively (Table 1). Mixotrophic ciliates did not correlate well with total nanoplankton in both abundance and biomass (Fig. 4). Overall regression of $A_{\mathrm{mc}}$ on $A_{\mathrm{n}}$ ex-
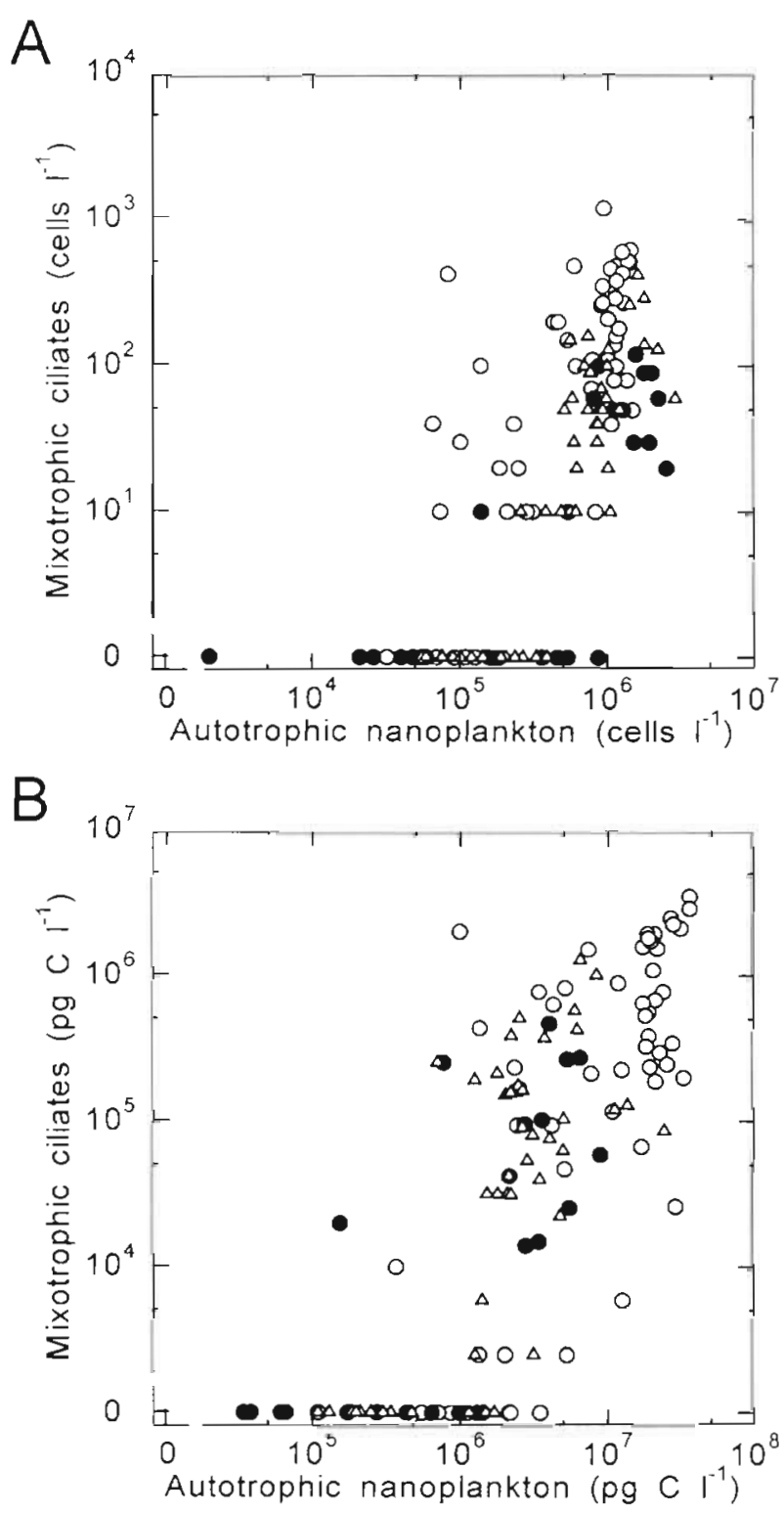

Fig. 5. Relationship in (A) abundance and (B) biomass between autotrophic nanoplankton and mixotrophic planktonic ciliates. (O) Spring subarctic water; ( fall subarctic water; ( $\Delta)$ subtropical water. One biomass datum $\left(3.96 \times 10^{2}, 0\right)$ at $200 \mathrm{~m}$ in fall subarctic water of 19 November 1991 ( $38^{\circ} 58^{\prime} \mathrm{N}, 144^{\circ} 30^{\prime} \mathrm{E}$ ) is excluded from (B)

cluding 38 samples with zero $A_{\mathrm{mc}}$ was: $A_{\mathrm{mc}}=2.09 \times 10^{-3}$ $\times A_{\mathrm{n}}{ }^{0.757}(\mathrm{r}=0.38, \mathrm{p}<0.001, \mathrm{n}=92)$. The regression equation in biomass was: $B_{\mathrm{mc}}=0.339 \times B_{\mathrm{n}}{ }^{0.823}(\mathrm{r}=0.48, \mathrm{p}<$ $0.001, n=92$ ). Correlation of mixotrophic ciliates to autotrophic nanoplankton was not close either (Fig. 5), being $A_{\mathrm{mc}}=1.74 \times 10^{-2} \times A_{\text {an }}{ }^{0.621}(\mathrm{r}=0.39, \mathrm{p}<0.001, \mathrm{n}=92)$ in abundance, and $B_{\mathrm{mc}}=0.682 \times B_{\mathrm{an}}{ }^{0.797}(\mathrm{r}=0.51, \mathrm{p}<0.001$, $\mathrm{n}=92)$ in biomass. Abundance $\left(A_{\mathrm{an}}\right)$ and biomass $\left(B_{\mathrm{an}}\right)$ of autotrophic nanoplankton were $3.2 \times 10^{4}$ to $1.46 \times$

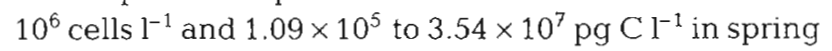


subarctic, $2 \times 10^{3}$ to $2.49 \times 10^{6}$ cells $l^{-1}$ and $3.96 \times 10^{2}$ to $8.71 \times 10^{6} \mathrm{pg} \mathrm{Cl}^{-1}$ in fall subarctic and $5.5 \times 10^{4}$ to $2.85 \times$ $10^{6}$ cells l$^{-1}$ and $1.09 \times 10^{5}$ to $2.37 \times 10^{7} \mathrm{pg} \mathrm{Cl}^{-1}$ in subtropical waters (Table 1).

Correlations of total ciliates and heterotrophic cillates to chl a concentration were high. These coefficients $(\mathrm{r})$ on logarithmic scales were $0.83(\mathrm{p}<0.001, \mathrm{n}=$ $124)$ in abundance and $0.81(p<0.001, n=124)$ in biomass of total ciliates and $0.79(\mathrm{p}<0.001, \mathrm{n}=123)$ in abundance and $0.77(\mathrm{p}<0.001, \mathrm{n}=123)$ in biomass of heterotrophic ciliates, when the samples with zero chl a concentration and zero ciliate abundance or biomass were excluded. On the other hand, that between mixotrophic ciliates and chl a concentration was not high: $0.57(\mathrm{p}<0.01, \mathrm{n}=92)$ in abundance and $0.49(\mathrm{p}<$ $0.05, \mathrm{n}=92$ ) in biomass.

\section{DISCUSSION}

Standing crops of ciliates observed in this study were $<2540$ cells $~^{-1}$ in abundance, or $<6.32 \times 10^{6} \mathrm{pg} \mathrm{C} \mathrm{l}^{-1}$ in biomass. These values are comparable to those reported from other oceanic waters. In Georges Bank in July, mean ciliate abundance in the water column above the depth of $1 \%$ light level was 580 to 13153 cells l$^{-1}$ (Stoecker et al. 1989). In the East China Sea in August, ciliate abundance and biomass in the top $200 \mathrm{~m}$ were 30 to 3040 cells $\mathrm{I}^{-1}$ and $2.02 \times 10^{4}$ to $1.07 \times 10^{7} \mathrm{pg} \mathrm{C} \mathrm{^{-1 }}$, respectively (Ota 1995). In the northwestern Indian Ocean during September and October, mean values of ciliate abundance and biomass in the euphotic zone were respectively 31 to 823 cells $\mathrm{I}^{-1}$ and $1 \times 10^{5}$ to $1.2 \times 10^{6} \mathrm{pg} \mathrm{Cl}^{-1}$ (Leakey et al. 1996).

Abundance and biomass of nanoplankton observed in this study were $7.2 \times 10^{4}$ to $3.18 \times 10^{6}$ cells l$^{-1}$ and $1.01 \times 10^{5}$ to $4.92 \times 10^{7} \mathrm{pg} \mathrm{Cl}^{-1}$, respectively. These values are also comparable to previously reported values from oceanic waters. In the Sargasso Sea during October and November, nanoplankton abundance in the top $20 \mathrm{~m}$ was $6.9 \times 10^{5}$ to $1.38 \times 10^{6}$ cells l$^{-1}$ (Caron 1983). In the Antarctic Ocean in March, average standing crop of nanoplankton in the surface water was $6.02 \times 10^{5}$ cells $\mathrm{I}^{-1}$, or $2.97 \times 10^{6} \mathrm{pg} \mathrm{Cl}^{-1}$ (Ishiyama et al. 1993).

Shrinkage and loss of cells due to fixation and preservation are serious problems in measurements of volume and abundance of ciliate cells. Fixation with $1 \%$ buffered formaldehyde causes significant shrinkage of the cells to $80-86 \%$ of live volume (Choi \& Stoecker 1989). Loss of cells by addition of formaldehyde is up to $20 \%$ of live counts (Dale \& Burkill 1.982). Even so, formaidehyde is reported to cause less shrinkage than other fixatives such as glutaraldehyde and acid Lugol's (Choi \& Stoecker 1989) and is considered to be the most appropriate fixative for examination of chlorophyll pigments contained in mixotrophic ciliates (Stoecker et al. 1994a). The ciliate cells examined in this study were subjected to such artifacts. However, correlations between ciliates and nanoplankton are likely valid, because the same fixation procedure was consistently employed throughout this study.

The correlation between ciliates and nanoplankton in biomass was strong $(\mathrm{r}=0.81, \mathrm{p}<0.001, \mathrm{n}=126)$ when all the data from the top 100 or $200 \mathrm{~m}$ of the water column are pooled (Fig. 2B). Correlation coefficients between them were also significantly high when the water column was divided into the surface layer shallower than $50 \mathrm{~m}(\mathrm{r}=0.64, \mathrm{p}<0.002, \mathrm{n}=67)$ and the underlying layer $(r=0.80, p<0.001, n=59)$ (Fig. 6). This indicates that standing crops of ciliates and nanoplankton co-vary geographically in a similar manner in both the layers, according to water types.

Planktonic ciliates are known to consume primarily both nanoplankton (Gifford 1985, Verity 1985) and picoplankton (Sherr \& Sherr 1987, Bernard \& Rassoulzadegan 1990). Standing crops of total ciliates and heterotrophic ciliates are correlated with nanoplankton at the community level (Figs. 2 \& 3). Since the correlation coefficients were larger when the standing crops were expressed in biomass, their predator-prey linkage might be very tight in the oceanic waters. Correlations between ciliates and picoplankton (bacterioplankton) were unknown in this study, because the latter was not measured. It is reported that the standing crop of bacterioplankton is stable over seasonal scales in various aquatic environments (e.g. Wright \& Coffin 1984, Tanaka et al. 1997) and this may explain the fact

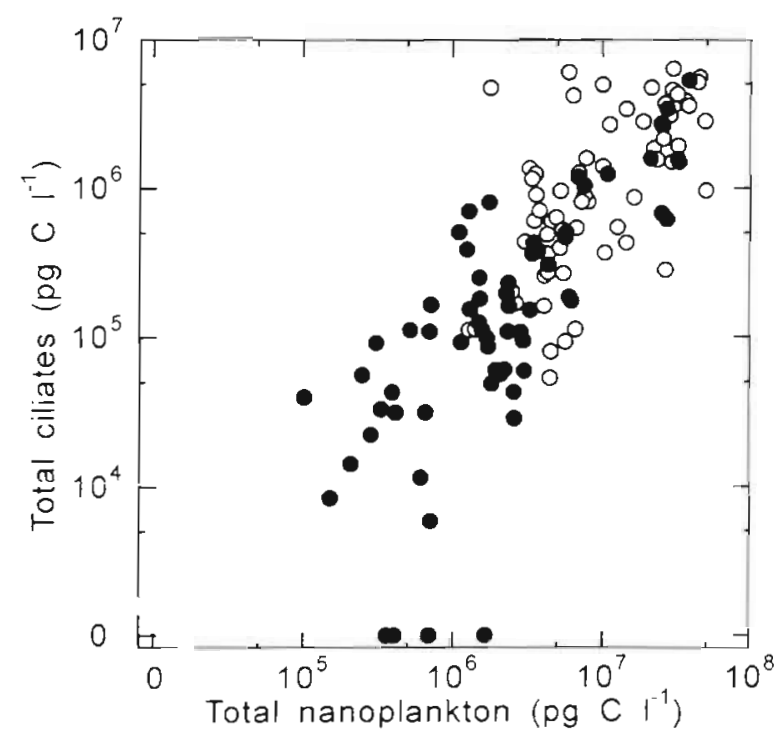

Fig. 6. Relationship in biomass between total nanoplankton and total planktonic ciliates. (0) Samples from the surface layer shallower than $50 \mathrm{~m}$; $(\bullet)$ those from the underlying layer deeper than $51 \mathrm{~m}$ 
that the correlation between ciliates and picoplankton in biomass over various sea areas is poor $(\mathrm{r}=0.14, \mathrm{n}=$ 87) (Lynn \& Montagnes 1991).

Mixotrophic ciliates did not show significant correlations with either total nanoplankton or autotrophic nanoplankton (Figs. 4 \& 5). Very few mixotrophic ciliates below the detection limit were frequently counted in deeper layers. Mixotrophic ciliates might be more or less selective feeders as they sequester the chloroplasts of particular types of algae (Jonsson 1987, Stoecker \& Silver 1987, Stoecker 1991), which remain functional (Jonsson 1987). If such a stenophagous character of mixotrophic ciliates is the case, differential vertical distributions of different nanoplankters (Furuya \& Marumo 1983, Olson et al. 1991) are likely the main reason for the lack of a significantly positive relationship between mixotrophic ciliates and total nanoplankton as well as autotrophic nanoplankton at the community level.

Whether prey organisms control size of predator populations or predator organisms control size of prey populations is an interesting question. If nanoplankton control ciliates, positive relationships are observed between the two (Gasol 1994). Although this study does not cover many components such as picoplankton, nanoplankton feeders other than ciliates and predators on ciliates, the strong positive correlations of the total ciliates and the heterotrophic ciliates on the nanoplankton are evident (Figs. $2 \& 3$ ). Size of the ciliate populations at community level is, as a whole, likely to be controlled in bottom-up manner by nanoplankton in open ocean. This trend indicates that the situation in the open ocean is possibly different from those in some coastal waters where top-down control on ciliate populations by metazoan predators prevails le.g. Smetacek 1981, Dolan 1991, Nielsen \& Kiørboe 1991, 1994, Kivi et al. 1993).

Acknowledgements. We thank Dr D. K. Stoecker for kindly teaching us the nanoplankton counting method. This work was supported by Sasakawa Scientific Research Grant 4-114 of the Japan Science Society and the grant 'Ocean Flux' from Japan Ministry of Education Science and Culture.

\section{LITERATURE CITED}

Bernard C, Rassoulzadegan F (1990) Bacteria on microflagellates as a major food source for marine ciliates: possible implications for the microzooplankton. Mar Ecol Prog Ser 64:147-155

Caron DA (1983) Technique for enumeration of heterotrophic and phototrophic nanoplankton, using epifluorescence microscopy, and comparison with other procedures. Appl Environ Microbiol 46:491-498

Choi JW, Stoecker DK (1989) Effects of fixation on cell volume of marine planktonic Protozoa. Appl Environ Microbiol 55: $1761-1765$

Dale T, Burkill PH (1982) 'Live counting' - a quick and sim- ple technique for enumerating pelagic ciliates. Ann Inst Oceanogr 58:267-276

Dolan JR (1991) Guilds of ciliate microzooplankton in the Chesapeake Bay. Estuar Coast Shelf Sci 33:137-152

Furuya K, Marumo R (1983) The structure of the phytoplankton community in the subsurface chlorophyll maxima in the western North Pacific Ocean. J Plankton Res 5:393-406

Gasol JM (1994) A framework for the assessment of topdown vs bottom-up control of heterotrophic nanoflagellate abundance. Mar Ecol Prog Ser 113:291-300

Gifford D (1985) Laboratory culture of marine planktonic oligotrichs (Ciliophora, Oligotrichida). Mar Ecol Prog Ser 23: $257-267$

Haas LW (1982) Improved epifluorescence microscopy for observing planktonic micro-organisms. Ann Inst Oceanogr 58:261-266

Ishiyama M, Hiromi J, Tanimura A, Kadota S (1993) Abundance and biomass distribution of microbial assemblages at the surface in the oceanic province of Antarctic Ocean. Proc NIPR Symp Polar Biol 6:6-20

Jonsson PR (1987) Photosynthetic assimilation of inorganic carbon in marine oligotrich ciliates (Ciliophora, Oligotrichina). Mar Microb Food Webs 2:55-68

Kivi K, Kaitala S, Kuosa H, Kuparinen J, Leskinen E, Lignell $R$, Marcussen B, Tamminen $\Upsilon$ (1993\}) Nutrient limitation and grazing control of the Baltic plankton community during annual succession. Limnol Oceanogr 38:893-905

Leakey RJG, Burkill PH, Sleigh MA (1996) Planktonic ciliates in the northwestern Indian Ocean: their abundance and biomass in waters of contrasting productivity. J Plankton Res 18:1063-1071

Lindholm T (1985) Mesodinium rubrum - unique photosynthetic ciliate. Adv Aquat Microbiol 3:1-48

Lynn DH, Montagnes DJS (1991) Global production of heterotrophic marine planktonic ciliates. In: Reid PC, Turley CM, Burkill PH (eds) Protozoa and their role in marine processes. Springer, London, p 281-307

Nielsen TG, Kiorboe T (1991) Effects of a storm event on the structure of the pelagic food web with special emphasis on planktonic ciliates. J Plankton Res 13:35-51

Nielsen TG, Kiørboe T (1994) Regulation of zooplankton biomass and production in a temperate, coastal ecosystem. 2 . Ciliates. Limnol Oceanogr 39:508-519

Olson RJ, Zettler ER, Chisholm SW, Dusenberry JA (1991) Advances in oceanography through flow cytometry. In: Demers $S$ (ed) Particle analysis in oceanography. Springer-Verlag, Berlin, p 351-399

Ota T (1995) Biomass and production of microzooplankton in the East China Sea with special reference to planktonic ciliates. Master's thesis, Tohoku Univ, Sendai (in Japanese with English abstract)

Pierce RW, Turner JT (1992) Ecology of planktonic ciliates in marine food webs. Rev Aquat Sci 6:139-181

Porter KG, Sherr EB, Sherr BF, Pace M, Sanders RW (1985) Protozoa in planktonic food webs. J Protozool 32:409-415

Putt M, Stoecker DK (1989) An experimentally determined carbon: volume ratio for marine 'oligotrichous' ciliates from estuarine and coastal waters. Limnol Oceanogr 34: $1097-1103$

Sherr EB, Sherr BF (1987) High rates of consumption of bacteria by pelagic ciliates. Nature $325: 710-711$

Smetacek V (1981) The annual cycle of protozooplankton in the Kiel Bight. Mar Biol 63:1-11

Sorokin YI (1981) Microheterotrophic organisms in marine ecosystems. In: Longhurst AT (ed) Analysis of marine ecosystems. Academic Press, New York, p 293-342

Stoecker DK (1991) Mixotrophy in marine planktonic ciliates: 
physiological and ecological aspects of plastid-retention by oligotrichs. In: Reid PC, Turley CM, Burkill PH (eds) Protozoa and their role in marine processes. Springer, London, p 161-179

Stoecker DK, Gifford DJ, Putt M (1994a) Preservation of marine planktonic ciliates: losses and cell shrinkage during fixation. Mar Ecol Prog Ser 110:293-299

Stoecker DK, Sieracki ME, Verity PG, Michaels AE, Haugen E, Burkill PH, Edwards ES (1994b) Nanoplankton and protozoan microzooplankton during the JGOFS North Atlantic bloom experiment: 1989 and 1990. J Mar Biol Assoc UK 74:427-443

Stoecker DK, Silver MW (1987) Chloroplast retention by marine planktonic ciliates. Endocytobiology III. Ann NY Acad Sci 503:562-565

Stoecker DK, Silver MW, Michaels AE, Davis LH (1988) Obligate mixotrophy in Laboea strobila, a ciliate which retains chloroplasts. Mar Biol 99:415-423

Stoecker DK, Taniguchn A, Michaels AE (1989) Abundance of autotrophic, mixotrophic and heterotrophic planktonic cili-

Editorial responsibility: John Dolan.

Villefranche-sur-Mer, France ates in shelf and slope water. Mar Ecol Prog Ser 50:241-254

Strathmann RR (1967) Estimating the organic carbon content of phytoplankton from cell or plasma volume. Limnol Oceanogr 12:411-418

Strickland JDH, Parsons TR (1972) A practical handbook of seawater analysis. Bull Fish Res Bd Can 167

Tanaka T, Fujita N, Taniguchi A (1997) Predator-prey eddy in heterotrophic nanoflagellate-bacteria relationships in a coastal marine environment: a new scheme for predatorprey associations. Aquat Microb Ecol 13:249-256

Verity PG (1985) Grazing, respiration, excretion, and growth rates of tintinnids. Limnol Oceanogr 30:1268-1282

Wessenberg $H_{1}$ Antipa GA (1970) Capture and ingestion of Paramecium by Didinium nasutum. J Protozool 17: $250-270$

Wright RT, Coffin RB (1984) Factors affecting bacterioplankton density and productivity in salt marsh estuaries. In: Klug MJ, Reddy CA (eds) Current perspectives in microbial ecology. American Society for Microbiology. Washington, DC, p 485-494

Submitted: November 8, 1995; Accepted: June 23, 1997 Proofs received from author(s): October 21, 1997 